\title{
1. Introduction: Poverty and human rights - a multidimensional concept in search of multidimensional collaboration
}

\section{Suzanne Egan}

\section{INTRODUCTION}

One might easily imagine that in most people's minds, poverty would generally be associated with human rights. Indeed, it has certainly been part of the rhetoric of human rights for decades - perhaps most famously characterised by an icon of the human rights movement, Nelson Mandela, as a fundamental issue of human rights, akin to slavery and apartheid. ${ }^{1}$ Yet it is only in recent decades that poverty has been analysed seriously from a human rights perspective, and arguments framed concerning the capacity of human rights to eradicate poverty. Within this burgeoning discourse, there are multiple disciplinary perspectives, each bringing distinctive insights on a range of issues including, for example, the role of human rights in defining poverty; whether poverty can be considered a violation of human rights or rather a cause and/ or a consequence of rights violations; and ultimately, whether poverty should or can realistically be addressed through the international human rights framework. Inevitably, the discourse reveals sites of contestation between as well as within particular disciplines, in common with the very concept of poverty itself. $^{2}$ The purpose of this introductory chapter is to provide some context for

\footnotetext{
1 See the full text of Nelson Mandela's speech in London's Trafalgar Square for the campaign to end poverty in the developing world, available at $<$ http://news.bbc.co.uk/ 2/hi/uk_news/politics/4232603.stm> accessed 22 July 2020.

2 In this respect, although lengthy, it is perhaps worth quoting in full the view expressed by Professor John Veit-Wilson to the Select Committee on Scottish Affairs of the UK Parliament: 'Poverty is a contested concept, and there is no agreement on how to define the word more precisely. Perceptions, contexts, meanings and usages differ between societies and observers, and change over time. The word is used indiscrimi-
} 
the collection that follows by providing a flavour of the complex issues that arise with respect to the interplay between poverty and human rights, and to illuminate the importance of interdisciplinary analysis and multidisciplinary engagement in confronting them. Section 2 focuses on definitional issues, outlining how human rights has come to be associated with definitions of poverty. Section 3 presents an analysis of various theoretical justifications for conceptualising poverty as an issue of human rights, while section 4 outlines some of the critiques and challenges that are confronted in integrating human rights into action on poverty in practice. The final section explains the structure of the book and summarises each of its individual chapters, which collectively elaborate in much greater detail the myriad of theoretical and practical issues arising when poverty is viewed in terms of human rights.

\section{ON THE DEFINITION OF POVERTY}

Scholarship on poverty, regardless of disciplinary focus, invariably begins with the author's perspective on how poverty should be defined and the extent of its reach, nationally and/or at the global level. Definitions and measurement are discrete issues but at some level intertwined because the way that poverty is defined will inevitably affect the way in which it is measured, as well as being instrumental in guiding policy responses. As Ruth Lister points out in her seminal work on poverty, there is no 'correct' definition of poverty and none is value neutral. ${ }^{3}$ Rather, a wide variety of definitions have been advanced. At the narrow end of the spectrum, these include defining poverty essentially in economic terms, by focusing on a person's income or material resources and consumption levels - as has traditionally been the approach taken by the World Bank, for example in measuring the extent of global poverty by reference to

nately for the concepts, definitions, signs or experiences of the condition, expressed by some as the characteristics of other people suffering it ("the poor") and by poor people in terms of their experience. It is used for disparate measurement methods as well as for their findings. It is often identified in the condition of lacking resources, necessities, or opportunities for participation, or suffering damage to human dignity or being socially excluded, as well as their deleterious concomitants and consequences. Many incompatible discourses are separately but simultaneously used in discussing its forms, scale, causes, consequences and cures, within and between industrialised societies and developing nations, often with little attempt to integrate the approaches': Select Committee on Scottish Affairs, Memoranda, July 2006; see $<$ https://publications.parliament.uk/pa/ cm200607/cmselect/cmscotaf/ucxxx/00103.htm> accessed 22 July 2020.

3 Ruth Lister, Poverty (Polity Press, 2004) 12-36. See also Caterina Ruggeri Laderchi, Ruhi Saith and Frances Stewart, 'Does It Matter that We Do Not Agree on the Definition of Poverty? A Comparison of Four Approaches' (2003) 31(3) Oxford Development Studies 243. 
shortfalls in consumption vis-à-vis fixed poverty lines. ${ }^{4} \mathrm{~A}$ broader conception of poverty, on the other hand, focuses instead on non-material elements such as lack of opportunities, vulnerabilities and social exclusion. ${ }^{5}$ This latter, multidimensional understanding of poverty has been greatly shaped by economist Amartya Sen's capability approach and, crucially, his identification of poverty in terms of 'capability deprivation', 6 whereby individual 'functionings' (and hence exposure to poverty) are subject to a wide range of heterogenous contingencies, including each individual's personal characteristics and their physical environment, social climate and relational perspectives (understood as established patterns of behaviour within particular communities). ${ }^{7}$ Sen's insights, developed in turn by philosopher Martha Nussbaum, ${ }^{8}$ led directly to the deployment of much more complex and granular tools for measuring poverty, such as the United Nations Development Programme's (UNDP) Global Multidimensional Poverty Index (MPI), ${ }^{9}$ which uses ten indicators across three dimensions of health (nutrition and child mortality), education (years of schooling and school attendance) and standard of living (access to electricity, sanitation, drinking water, housing and assets) in order to identify

4 The World Bank has defined extreme poverty as living below US\$1.90 per day in 2011 purchasing power parity terms which is calculated by reference to the poverty thresholds in the poorest 15 countries: see <https://www.worldbank.org/en/topic/ poverty/overview $>$ accessed 23 July 2020. The Bank's approach has been roundly criticised by human rights proponents for producing a distorted impression of the reality of global poverty. See the final report of Philip Alston in his capacity as Special Rapporteur on Extreme Poverty and Human Rights to the UN Human Rights Council on The Parlous State of Poverty Eradication, in which he describes the Bank's international poverty line as being '[...] explicitly designed to reflect a staggeringly low standard of living, well below any reasonable conception of a life with dignity. Under the measure, one can "escape" from poverty without an income anywhere near that required to achieve an adequate standard of living, including access to healthcare and education': UN Doc. A/HRC/44/40, 2 July 2020, para. 12.

5 United Nations, Rethinking Poverty Report on the World Social Situation 2010 (New York, 2009) 45. See <https://www.un.org/esa/socdev/rwss/docs/2010/fullreport .pdf $>$ accessed 22 July 2020.

6 Sen refers to the idea of capability as 'the opportunity to achieve valuable combinations of human functionings - what a person is able to do or be': Amartya Sen, 'Human Rights and Capabilities' (2005) 6 Journal of Human Development 151, 153.

7 Amartya Sen, The Idea of Justice (Allen Books, 2009) 254-7.

8 Martha Nussbaum, Creating Capabilities: The Human Development Approach (Harvard University Press, 2011).

9 United Nations Development Programme, 'The 2020 Multidimensional Poverty Index' (Human Development Reports, 2020). See <http://hdr.undp.org/en/2020 -MPI> accessed 22 July 2020. 
people who are multidimensionally poor. ${ }^{10}$ By calculating deprivation scores for each indicator as between people living in the same households, the MPI helps to show how the lived experience of poverty can vary hugely in intensity across individual countries and even within households, in a way that could never be projected if relying on income data alone. ${ }^{11}$

Poverty is defined more specifically, in terms of 'absolute' poverty - which signifies a condition in which a person lacks the basic means of survival (commonly understood in terms of severe deprivation of the minimal levels of nutrition required to survive and basic goods) $)^{12}$ - and 'relative' poverty, which brings into play the social context in which poverty is experienced as a vital element of the predicament. ${ }^{13}$ This latter understanding of poverty as a relative concept is now universally accepted, with most scholarship recognising that absolute poverty has relative aspects ${ }^{14}$ and even the World Bank moving recently to incorporate societal poverty lines in measuring poverty. ${ }^{15}$

The framing of poverty in human rights terms is of comparatively recent vintage and it is clear that in this respect, human rights bodies have been heavily influenced by the capabilities approach. In its Statement on Poverty and the International Covenant on Economic, Social and Cultural Rights in 2001, for example, the Committee on Economic, Social and Cultural Rights (CESCR) defined poverty as 'a human condition characterized by sustained or

10 See further United Nations Development Programme, Human Development Report 2019: Beyond Income, Beyond Averages, Beyond Today: Inequalities in Human Development in the 21st Century, Technical Note 5 (New York, 2019) $10<\mathrm{http}: / / \mathrm{hdr}$ .undp.org/sites/default/files/hdr2019_technical_notes.pdf $>$ accessed 22 July 2020.

${ }_{11}$ The 2020 MPI shows that of the 1.3 billion people living across 107 developing countries, 67 per cent are living in multidimensional poverty and more than two thirds live in middle-income countries. The report also shows that 803 million multidimensionally poor people live in a household where someone is undernourished, 476 million have an out-of-school child at home, 1.2 billion lack access to clean cooking fuel, 687 million lack electricity and 1.03 billion have substandard housing materials: (n 9) 3 .

12 Udaya Wagle, 'Re-thinking Poverty: Definition and Measurement' (2002) 54 International Social Science Journal 183, 183.

13 As Lister notes, a widely used definition of poverty is the one pioneered by sociologist Peter Townsend, which expresses the relative nature of poverty as well as recognising it in multidimensional terms: 'Individuals, families and groups in the population can be said to be in poverty when they lack resources to obtain the type of diet, participate in the activities and have the living conditions and amenities which are customary, or at least widely encouraged and approved, in the societies in which they belong': Lister (n 3) 21.

14 ibid 20-8.

15 Espen Beer Prydz and Dean Jolliffe, Societal Poverty: A Global Measure of Relative Poverty (The World Bank, 2019). See $<$ http://datatopics.worldbank.org/world -development-indicators/stories/societal-poverty-a-global-measure-of-relative-poverty .html> accessed 22 July 2020. 
chronic deprivation of the resources, capabilities, choices, security and power necessary for the enjoyment of an adequate standard of living and other civil, cultural, economic, political and social rights'. ${ }^{16}$

This multidimensional understanding of poverty, in the Committee's view, 'reflects the indivisible and interdependent nature of all human rights' ${ }^{17}$ Likewise, successive office holders of the position of UN Special Rapporteur on Extreme Poverty and Human Rights have long since adopted a broad view of extreme poverty as encompassing not only income poverty but also human development poverty and social exclusion. ${ }^{18}$ Indeed, as far back as 1996, the first office holder defined extreme poverty as a lack of 'basic security' to assume basic responsibilities and to enjoy fundamental rights, ${ }^{19}$ and was expressly critical of 'reductionist' methods of calculating poverty based on income levels alone used by the World Bank. ${ }^{20}$

The integration of material deprivation and capability failure with human rights standards arguably brings to the table, and serves to address, aspects of poverty that other definitions fail to capture. These aspects include the psychological impact of poverty experienced through feelings of stress and shame, as well as the sociological phenomenon of 'othering' which the stigma of poverty simultaneously induces. ${ }^{21}$ Numerous empirical studies attest to the existence of these phenomena in both high-income and low-income countries, and to the fact that they are driven by a discourse of 'myth, moral judgements and misconceptions' increasingly prevalent in media portrayals, political commentary ${ }^{22}$ and even policies ostensibly aimed at alleviating poverty. ${ }^{23}$ The

16 CESCR, Statement on Poverty and the ICESCR, UN Doc. E/C.12/2001/10, 10 May 2001, para. 8. See <https://digitallibrary.un.org/record/452397? $1 \mathrm{n}=$ en $>$ accessed 22 July 2020.

17 ibid.

18 Report of the Independent Expert on the Question of Human Rights and Extreme Poverty, UN Doc. A/HRC/7/15, 28 February 2008, para. 31. See $<$ https://undocs.org/ en/A/HRC/7/15> accessed 22 July 2020.

19 Report of the Special Rapporteur appointed by the Sub-Commission on Prevention of Discrimination and Protection of Minorities on Human Rights and Extreme Poverty UN Doc. E/CN.4/Sub.2/1996/13, Annex 3, 28 June 1996.

20 ibid paras 49-50.

21 Kayleigh Garthwaite, 'Stigma, Shame and "People Like Us": An Ethnographic Study of Foodbank Use in the UK' (2016) 24(3) The Journal of Poverty and Social Justice $277-89$.

22 ibid 278. See further, Tracy Shildrick and Robert MacDonald, 'Poverty Talk: How People Experiencing Poverty Deny Their Poverty and Why They Blame "The Poor"” (2013) 61 The Sociological Review 285-303.

23 Robert Walker's seminal work The Shame of Poverty (OUP, 2014) examines these issues in the context of the lived experiences of low-income families in societies as diverse as Norway and Uganda, Britain and India, China, South Korea and Pakistan. 
consequences of this "poverty-shame nexus" ${ }^{24}$ - which include adverse health consequences, social retreat and erosion of the social fabric - are also well documented. ${ }^{25}$ Building on these insights, Lister makes a powerful argument regarding the positive role that the 'counter-discourse' of human rights can play in reframing poverty:

By strengthening political agency and counteracting the shame of poverty, the language of human rights has made it easier to develop a collective identity with others living in poverty. It helps to counter the process of Othering because it emphasises what we share as human beings rather than what separates us. ${ }^{26}$

Nevertheless, the notion of defining poverty with reference to human rights is by no means universally accepted. As Donald and Mottershaw point out, 'there is little evidence of governments using human rights to define or measure poverty operationally in their national spheres',${ }^{27}$ much less powerful institutions such as the World Bank. ${ }^{28}$ Indeed, when it comes to defending their record on poverty, governments have been known to tout the definition of absolute poverty as an appropriate benchmark rather than acknowledge the multidimensional and relative nature of poverty, and to deny the gamut of related human rights claims. ${ }^{29}$

The remaining sections of this chapter thus aim to unpack the normative arguments advanced and the practical challenges faced in attempts to integrate

See further, Erika Gubrium, Sony Pellissery and Ivar Lødemel (eds) The Shame of It: Global Perspectives on Anti-Poverty Policies (Bristol University Press, 2014).

24 Yongmie Nicola Jo, 'Psycho-Social Dimensions of Poverty: When Poverty Becomes Shameful' (2012) 33(3) Critical Social Policy 514-41, 516 cited by Ruth Lister, 'To Count for Nothing: Poverty Beyond Statistics' (2015) 3 Journal of the British Academy, 139-65, 142.

25 Elaine Chase and Robert Walker, 'The Co-Construction of Shame in the Context of Poverty: Beyond a Threat to the Social Bond' (2013) 47(4) Sociology 739-54.

26 Lister (n 24) 155 and see also Poverty (n 3) 158-75.

27 Alice Donald and Elizabeth Mottershaw, Poverty, Inequality and Human Rights (Rowntree Foundation, 2009) 12. See <https://www.jrf.org.uk/report/poverty -inequality-and-human-rights $>$ accessed 22 July 2020.

28 See the Report of the Special Rapporteur on Extreme Poverty and Human Rights on the human rights policy of the World Bank, in which he famously cast the bank as a 'human rights-free zone': UN Doc. A/70/274, 4 August 2015, para. $68<\mathrm{https} / /$ www .ohchr.org/EN/Issues/Poverty/Pages/AnnualReports.aspx.> accessed 22 July 2020.

29 See, for example, the Reports of the Special Rapporteur on Extreme Poverty and Human Rights on his visits to the United Kingdom of Great Britain and Northern Ireland, UN Doc. A/HRC/41/39/Add.1, 23 April 2019, paras 17-19; the United States, UN Doc. A/HRC/38/33/Add.1, 4 May 2018, para. 12; and China, UN Doc. A/ HRC/35/26/Add.2, 28 March 2017, para. 22. 
human rights into overall conceptions of poverty and strategies aimed at its eradication.

\section{CONCEPTUAL FOUNDATIONS}

In order for poverty to be effectively framed as a human rights issue, the conceptual linkage between poverty and human rights needs to be convincingly established and elaborated. At a time when the charge of so-called human rights inflation is increasingly raised as a critique of human rights discourse generally, the linkage cannot simply be asserted, given some very specific accusations of unacceptable overreach or 'rhetorical incantations' in the application of a human rights lens to the phenomenon of poverty. ${ }^{30}$ The conceptual connection has been explored by philosophers, sociologists, and legal theorists, typically aiming to elucidate the connection through an argument that poverty is a violation of human rights per se or that poverty is a cause or a consequence of human rights violations.

At the philosophical level, Osmani, for example, argues that poverty is a violation of human rights by drawing on Sen's capability approach. ${ }^{31}$ Starting from the premise that the capability view of poverty is now widely accepted, he contends that Sen's 'goal rights' system, and more specifically his notion of 'capability rights' as the means to achieve society's goals, provides the conceptual foundation for human rights. Since the human rights obligations of States to respect, protect and fulfil mirror the same freedoms of capability rights, human rights can thus be seen as 'rights to capabilities'. This latter proposition, in combination with the view of poverty as capability failure, thus points to the logical conclusion that poverty is a violation of human rights. ${ }^{32}$ Not all denials of human rights, however, may be regarded as constitutive of poverty - only denials of those rights that correspond to the capabilities considered 'basic' by a given society with the further quid pro quo that 'inadequate command over economic resources' must play a role in the causal chain leading to the

30 See, for example, Hurst Hannum, Rescuing Human Rights (Cambridge University Press, 2019) 64-5 in regard to Alston's critique of the World Bank's refusal to embrace the human rights framework in its analysis of poverty. See also Dominique Clément, 'Human Rights or Social Justice? The Problem of Rights Inflation' (2018) 22 International Journal of Human Rights 155-69.

31 Siddiqur Rahman Osmani, 'Poverty and Human Rights: Building on the Capability Approach' (2005) 6(2) Journal of Human Development 205-19.

32 ibid 208-13. For an explanation and analysis of Sen's goal rights system, see Graham Finlay, 'The Philosophical Development of Human Rights' in Suzanne Egan (ed), International Human Rights: Perspectives from Ireland (Bloomsbury, 2015) 11, $18-21$. 
denial of rights. ${ }^{33}$ Other rights - most notably civil and political rights - may also have instrumental or constraint-based relevance to poverty such that they may still play a role in poverty discourse and in poverty-reduction strategies. ${ }^{34}$

Nickel, on the other hand, sets the bar rather lower in his analysis of the conceptual connection in play between poverty and human rights. ${ }^{35}$ In contrast to Osmani's embrace of the capability approach - an approach that emphasises the moral importance of freedom to achieve well-being and equality - as the foundation for human rights, Nickel starts from the position that human rights are not ideals for the good life, but rather are concerned with 'ensuring the conditions, negative and positive, of a minimally good life' ${ }^{36}$ From this premise he argues that in contrast to 'grandiose' international human rights documents, the only economic and social rights which can justifiably and feasibly be designated as human rights are those which focus on survival, health and education. ${ }^{37}$ Given that severe poverty violates these rights, such rights generate high-priority obligations on everyone - individuals, governments and corporate entities - to work towards its elimination. Thus, while Nickel perceives the range of duty holders to be wide, his conception is limited in terms of the scope of rights envisaged as well as the level of poverty ('severe') implicated. ${ }^{38}$

Thomas Pogge locates the conceptual connection between poverty and human rights in the right to secure access to an adequate standard of living. Non-fulfilment of this right, in his view, typically results in a lack of secure access to the objects of other human rights. ${ }^{39}$ His distinctive contribution to a theoretical understanding of the relationship between poverty and human rights is his advancement of an institutional approach to rights, whereby governments and individuals have responsibilities to work towards an institutional order that ensures all individuals have access to these rights. ${ }^{40}$ Like Mandela, Pogge equates severe poverty with slavery, ultimately arguing that 'the imposition of social institutions that perpetuate these deprivations constitutes a violation of the human rights of those who are impoverished or enslaved' ${ }^{41}$

\footnotetext{
33 ibid 215.

34 ibid 216-17.

35 James Nickel, 'Poverty and Human Rights' (2005) 55 The Philosophical Quarterly 385.

36 ibid 386.

37 ibid 287-389.

38 ibid 402.

39 Thomas Pogge, 'Are We Violating the Human Rights of the World's Poor?' (2011) 14 Yale Hum Rts \& Dev LJ 1.

40 Thomas Pogge, 'How Should Human Rights Be Conceived?' in Thomas Pogge (ed) World Poverty and Human Rights: Cosmopolitan Responsibilities and Reforms (Polity Press, 2008) 58-76.

41 ibid 20.
} 
Each of these accounts of poverty as a violation of human rights have been critiqued on their own merits and they are by no means the only theoretical accounts on offer..$^{42}$ The point of highlighting them here is to demonstrate that even as a moral proposition, the assertion of poverty as a violation of human rights is as varied as it is contested. As Fernanda Doz Costa points out, however, the consequences of arguing that poverty is a violation of human rights are significantly different when the proposition is made as a matter of international human rights law. ${ }^{43}$ This is because the claim that poverty is a violation of international human rights law carries with it the necessary corollary that States are legally obliged to take action to address the situation, and further, that they are accountable and subject to review of their efforts by international human rights bodies. Hence, the task of establishing a connection between poverty and human rights which is firmly grounded in legally binding human rights obligations is arguably more challenging given the stakes that are in play.

In this respect, Polly Vizard approaches the task by constructing a 'human rights-based capability framework' whereby recognised international human rights standards may be explicitly adopted as a basis (i) to specify a precise list of capabilities; and (ii) to identify and allocate the general and specific duties on internationally recognised obligation-holders. ${ }^{44}$ Noting that Sen deliberately eschews framing a list of capabilities, while Nussbaum's proposed list of central capabilities ${ }^{45}$ is criticised on legitimacy grounds, she contends that the broader framework of human rights law can supply these deficiencies by supporting and reinforcing the content of basic capabilities. Thus, she contends, authoritative interpretations of the International Covenant on Economic, Social and Cultural Rights provide a basis for taking forward the idea of a 'capability to achieve an adequate standard of living' as the '[...] "[h]uman right to a standard of living adequate for health and wellbeing" - including adequate nutrition, safe water and sanitation, shelter and housing, and access

42 On Pogge's view alone, for example, see Thomas Pogge, 'Are We Violating the Human Rights of the World's Poor: Responses to Four Critics' (2014) 17 Yale Hum Rts \& Dev LJ 74.

43 Fernanda Doz Costa, 'Poverty and Human Rights from Rhetoric to Legal Obligations: A Critical Account of Conceptual Frameworks' (2008) 9 Intl J Human Rights 80-106, 85.

44 Polly Vizard, 'Specifying and Justifying a Basic Capability Set: Should the International Human Rights Framework be Given a More Direct Role?' (2007) 35 Oxford Development Studies 225; and see further Polly Vizard, Poverty and Human Rights (Oxford University Press, 2006), chapter 5.

45 See Martha Nussbaum (n 8) 33-4. 
to basic health, social services and education' that governments are obliged to respect, protect and promote. ${ }^{46}$

Doz Costa correctly worries that this approach needs development in terms of the linkage between poverty and the violation of civil and political rights. ${ }^{47}$ But as she acknowledges, Vizard's theory does add value in its attempt to construct a cross-disciplinary framework between the capability approach and international human rights law. ${ }^{48}$ Indeed, sharpening the former with the specificity and detail supplied by the latter can serve to concretise the concept of capabilities for the human rights practitioner, as well as giving capabilities the sense of urgency inherent in the language of human rights. It might also be argued that the integration of the language of capabilities into the interpretation of international human rights law in turn helps to focus more squarely on the question of what may actually be required to secure a right for the benefit of a given person or group of persons, and hence to extrapolate the positive obligations on States in respect of the given right. ${ }^{49}$ Thus, for example, conceptualising the right to an adequate standard of living in terms of capabilities ('What can each person be and do?') helps us not only to see that each person has a right to housing, food, clothing and so on, but also to envision in very concrete terms the specific requirements necessary to secure each of these various elements of the general right to a sufficient threshold of capability for each individual in a given society, and hence what each government must do to make the right a reality - or, to use the language of human rights, to make these available, accessible, acceptable and adaptable for its country's inhabitants.

Another way of conceptualising the linkage between poverty and human rights in legal terms is to do so instrumentally, by conceiving of poverty as a cause or a consequence of human rights denials. ${ }^{50}$ This approach has a number of advantages in bringing conceptual clarity to the task of linking the phenomenon of poverty with the fundamental principles of international human rights law. First, when poverty is seen as a cause or a consequence of human rights violations, this acknowledges the complexity of the circumstances that give rise to poverty and the fact it may not always be possible to

\section{Vizard (n 44) 242. \\ Doz Costa (n 43) 93. \\ ibid.}

49 'In short, thinking in terms of capability gives us a benchmark in thinking about what it is really to secure a right to someone': Martha Nussbaum, 'Capabilities and Human Rights' (1997) 6 Fordham Law Rev. 273, 294. See further, Polly Vizard, Sakiko Fukuda-Parr and Diane Elson, 'Introduction: The Capability Approach and Human Rights' (2011) 12 Journal of Human Development and Capabilities 1-22: 'The emergence of a capability-based understanding of human rights also helps to provide stronger foundations for the notion of positive obligation' (at 2).

50 This is the approach preferred by Doz Costa (n 43) 93-5. 
attribute responsibility for poverty directly to government policy and practices, when other direct causes or actors are at work. This perspective thus helps to focus instead from a theoretical standpoint on the full range of duties that are owed by States to respect, protect and fulfil human rights obligations under international human rights law. ${ }^{51}$ Thus, even in circumstances where it may be difficult to show that a government is wholly responsible for circumstances of poverty, it follows that it will nonetheless be obliged as a matter of international human rights law to address ('fulfil') the human rights denials being experienced by victims of poverty that may help to relieve their plight. ${ }^{52}$ At the same time, the obligation 'to respect' brings into play the negative obligations on government not to create conditions which push people into poverty or keep them there without meaningful access to or enjoyment of rights through its fiscal policies and implementation of the political economy. Furthermore, while the positive obligations to protect, and crucially to fulfil, have particular salience in regard to material deprivations of the economic, social and cultural rights commonly experienced by people in poverty, they can also be seen to have immense importance with respect to non-material deprivations of civil and political rights typically experienced by people in poverty, such as the rights to political participation, security of the person and access to justice. ${ }^{53}$ This underscores the importance of not conflating poverty with economic, social and cultural rights and the relevance in this context of the important principles of universality, indivisibility and interdependence on which international human rights law is based. Civil and political rights may also be viewed in this sense as having causative relevance in preventing poverty, as well as being centrally important in underpinning the key principles of accountability, participation and non-discrimination on which human rights-based approaches to poverty and development are explicitly based.$^{54}$ While it can be argued that

51 For an overview of the 'vocabulary' of obligations owed by States under international human rights law, see Frédéric Mégret, 'Nature of Obligations' in Daniel Moeckli, Sangeeta Shah and Sandesh Sivakumaran (eds), International Human Rights Law (3rd edn, Oxford University Press, 2018) 86, 97-9.

52 For a fuller discussion of these basic principles, see International Council on Human Rights Policy, Duties Sans Frontières: Human Rights and Global Social Justice (2003) 19-21 <https://ssrn.com/abstract=1551241> accessed 22 July 2020.

53 For practical insights on the relevance of civil and political rights to people living in poverty, see the Report of the Special Rapporteur on Extreme Poverty and Human Rights on his mission to the United States of America, UN Doc. A/HRC/38/33/Add.1, 4 May $2018<$ https://digitallibrary.un.org/record/1629536? $\ln =\mathrm{en}>$ accessed 22 July 2020.

54 See OHCHR, Human Rights and Poverty Reduction: A Conceptual Framework (United Nations, 2004) <https://www.ohchr.org/Documents/Publications/ PovertyReductionen.pdf $>$ accessed 22 July 2020. 
the approach of viewing poverty and human rights thus in instrumental terms does not go far enough in addressing the structural causes of human rights violations, ${ }^{55}$ it does perhaps offer the clearest conceptual basis on which the linkage between poverty and international human rights law can be framed.

\section{CRITIQUES AND CHALLENGES}

Yet, however enthusiastically this linkage between poverty and the international human rights framework may be asserted, the journey between abstract theory and implementation in practice is very much a work in progress, and one that brings with it a number of critiques as well as a myriad of critical challenges. ${ }^{56} \mathrm{~A}$ few can be mentioned here and are explored further, along with others, in the chapters of this book.

The first explicit critique, ${ }^{57}$ alluded to earlier, is the one mounted from within and outside the field of so-called rights inflation; that is, that the human rights framework is being inappropriately marshalled in support of a wide range of issues, including poverty, to which it was never meant to apply. ${ }^{58}$ Clément, for example, is a strident proponent of this view, arguing that human rights are a 'poor language' for articulating grievances such as poverty, which he characterises as being ultimately a question of social justice best dealt with by social justice strategies. ${ }^{59}$ In a striking rebuff to the importance of human rights in mobilising and empowering individuals and communities, ${ }^{60}$ he maintains that a human rights approach is ultimately counterproductive in that it fails to address root causes, raises expectations and is incapable of effecting the kind of redistribution that is necessary to eradicate poverty. ${ }^{61}$ Hannum also cites poverty and development among the examples he raises of ill-advised overreach on the part of human rights advocates - a tendency that he decries as being misplaced and unrealistic in its capacity to deliver. ${ }^{62}$

55 Susan Marks, 'Human Rights and Root Causes' (2011) 74(1) The Modern Law Review 57-78.

56 For an overview of resistance to human rights discourse in economic thinking in particular, see Stephen Marks, 'Poverty' in Moeckli et al. (n 51) 597, 602-7.

57 I use the term 'explicit challenge' here to differentiate these from standard critiques about the entire corpus of international human rights law: see generally, Marie-Bénédicte Dembour, 'Critiques' in Moekli et al. (n 51) 41.

58 The term appears to have been first coined by Michael Ignatieff in 'Human Rights as Idolatry' in Amy Gutman (ed), Human Rights as Politics and Idolatry (Princeton University Press, 2003) 286, cited in Hannum (n 30) 57.

59 Clément (n 30) 156.

60 Lister, text accompanying (n 26).

61 Clément (n 30) 158.

62 Hannum (n 30) 61-7. 
In response to the charge of 'rights inflation' generally, Petrasek has convincingly argued that such analysis frequently ignores the reality that 'truly "new" rights are rarely advanced, rather most rights proliferation and expansion arises from an ongoing process of interpreting and applying existing rights to new - or newly acknowledged - realities'. ${ }^{63}$ This point has particular resonance with respect to poverty - by no means a new phenomenon, but one that (as highlighted in the previous section) is increasingly seen in philosophical, political and legal terms as bringing into play human rights duties and obligations on a wide range of actors, most particularly governments. These insights, spurred on in no small part by the dramatic impact of the global financial crisis of 2008, have generated a significant body of scholarship and analysis on the connection between the normative framework of human rights and economic and social policies that give rise to or perpetuate poverty; the precise content of relevant rights; and the need to apply these insights in designing, implementing and monitoring national and global fiscal policies aimed at poverty eradication. ${ }^{64}$ Rather than being viewed as an exercise in rights inflation, it seems more accurate to regard these initiatives as a concerted attempt on the part of the human rights movement to underscore, reinforce and extrapolate in much needed detail the relevance of human rights to poverty, the obstacles to its eradication and the obligations of States in tackling it at the national and global level. ${ }^{65}$ This is an endeavour that has taken on a new urgency and apparently heightened interest given the ravages of COVID-19 and its effects on the global poor.

In a related (albeit differently reasoned) critique, Samuel Moyn essentially discounts these efforts, arguing instead that the human rights movement has been of very limited use in tackling poverty. ${ }^{66}$ The basis for this stinging rebuke is the charge that the movement has failed to challenge the insurgence of neoliberalism and has in fact bolstered market fundamentalism by focusing

63 David Petrasek, 'Rights-Inflation: What's the Problem?' (Open Global Rights, 19 February). See $<$ https://www.openglobalrights.org/human-rights-inflation-whats-the -problem/> accessed 13 July 2020.

64 United Nations, Guiding Principles on Extreme Poverty and Human Rights (UN Human Rights Council, 2012). See <https://www.ohchr.org/en/issues/poverty/pages/ dgpintroduction.aspx $>$ accessed 22 July 2020.

65 On the development of theory regarding transnational obligations of States, see Duties Sans Frontières (n 52) and Margot Salomon, 'Why Should It Matter that Others Have More? Poverty, Inequality, and the Potential of International Human Rights Law' (2011) 37(5) Review of International Studies 2137-55.

${ }_{66}$ As he argues, 'the critical reason that human rights have been a powerless companion of market fundamentalism is that they have simply nothing to say about material inequality': Samuel Moyn, Not Enough: Human Rights in an Unequal World (Harvard University Press, 2018) 21. 
too much on the goal of achieving material sufficiency, as opposed to material equality, through its weak elaboration and advocacy of economic and social rights. ${ }^{67}$ By forsaking the goal of material equality and championing instead status equality, Moyn argues, the human rights movement has exacerbated rather than narrowed the gap between the global rich and poor. ${ }^{68}$ De Búrca's robust review of Moyn's thesis justly depicts it as 'a peculiarly one-eyed and exaggerated account of the human rights movement in general and its engagement with socio-economic injustice'. ${ }^{69}$ As she points out, Moyn's argument appears to miss the mark by apparently ignoring a central tenet of human rights - the principle of interdependence - and, in so doing, treating the work done by the human rights movement on status equality and material equality as entirely separable.

There seems to be an assumption in each of these critiques, moreover, that because a human rights approach may not supply all the answers to the complexity of the phenomenon to poverty and inequality, it has signally 'failed' (in Moyn's analysis) or has no place in strategies aimed at addressing poverty, as suggested by Clément. At the same time, as Marks describes, there is often a complete resistance to human rights discourse in other discourses on poverty. ${ }^{70}$ Thus, while many economists will reference broadly the same concerns as human rights scholars and practitioners when discussing approaches and methods to eradicate poverty - such as the need for fairness, accountability, transparency, decent labour standards, and so on - many of them rarely refer directly to human rights standards or treaties. A more balanced appraisal, however, would suggest that the application of a human rights lens to the phenomenon of poverty and to strategies for development can complement rather than detract from other approaches. ${ }^{71}$ The insight that poverty is a mul-

67 Indeed, in the conclusion of his analysis, Moyn goes so far as to state that 'even perfectly realised human rights are compatible with radical inequality': ibid 2013.

68 For a very condensed version of Moyn's central argument, see Samuel Moyn, 'Human Rights and the Age of Inequality: The Human Rights Regime and Movement Are Simply Not Equipped to Challenge Global Inequalities' (Open Global Rights, 27 October) <https://www.openglobalrights.org/human-rights-and-age-of -inequality/> accessed 13 July 2020.

${ }_{69}$ Gráinne De Búrca, 'Samuel Moyn, Not Enough: Human Rights in an Unequal World' (2018) 16(4) International Journal of Constitutional Law 1347-80, 1349.

70 Susan Marks, 'Human Rights and the Bottom Billion' (2009) 1(1) European Human Rights Law Review 37-49.

${ }_{71}$ In this respect, see the arguments made by Philip Alston as to the need to accept limitations of human rights-based approaches to development which would seem to be apt in respect of developing and developed countries: 'Ships Passing in the Night: The Current State of the Human Rights and Development Debate Through the Lens of the Millennium Development Goals' (2005) 27 Human Rights Quarterly 755-829, 802-7. 
tidimensional problem inevitably points to the conclusion that its eradication necessarily requires multidimensional thinking and action both at an interdisciplinary and a multidisciplinary level, and that no single approach could possibly do all the work. In this respect, evidence suggests that incorporating human rights into action on poverty serves to empower and mobilise individuals and communities, build alliances between disparate groups, sway public opinion and potentially influence, but not necessarily dictate, policy formation and practical action. ${ }^{72}$

Nevertheless, these critiques need to be taken seriously, as they signal some of the reasons why the relationship between poverty and human rights is intensely resisted (even within the scholarly community) and the multiple challenges that arise in having a human rights perspective significantly embedded in strategies for poverty eradication. These include the ongoing challenge of articulating the precise content of the normative obligations owed by States in this context, particularly with respect to economic, social and cultural rights, as well as regarding the requirements of accountability, non-discrimination and participation. Further, at a normative level, there is a need to place greater emphasis on the inextricable relationship between poverty and extreme inequality, and for more deliberate and concrete engagement with questions of resources and redistribution. ${ }^{73}$ There is evidence that human rights bodies are increasingly receptive to addressing the human rights implications of inequality ${ }^{74}$ yet the task of translating in accessible terms - and, above all, convincing policy makers of the relevance of human rights to public laws and policies that directly impact poverty and inequality, such as taxation, ${ }^{75}$ privatisation $^{76}$ and

72 Donald and Mottershaw (n 27).

73 Philip Alston, 'Extreme Inequality as the Antithesis of Human Rights' (Open Global Rights, 27 August). See $<$ https://www.opendemocracy.net/en/openglobalrights -openpage/extreme-inequality-as-antithesis-of-human-rights/> accessed 17 July 2020. See also Gaby Oré Aguilar and Ignacio Saiz, 'Tackling Inequality as Injustice: Four Challenges for the Human Rights Agenda' (Open Global Rights, 30 March) $<$ https:// www.opendemocracy.net/en/openglobalrights-openpage/tackling-inequality-as -injustice-four-challenges-for-h/> accessed 17 July 2020.

74 Stephen Jensen, 'Inequality a Prominent Concern for UN Human Rights Monitors' (Open Global Rights, 4 December). See https://www.openglobalrights .org/inequality-a-prominent-concern-for-UN-human-rights-monitors/ accessed 17 July 2020.

75 See the Report of the Special Rapporteur on Extreme Poverty and Human Rights, Magdalena Sepúlveda Carmona, UN Doc. A/HRC/26/28, 22 May 2014; and see further, Philip Alston and Nikki Reisch, 'Tax, Inequality and Human Rights' (Oxford Scholarship Online, 2019).

76 See the Report of Special Rapporteur on Extreme Poverty and Human Rights, Philip Alston on Privatisation, Extreme Poverty and Human Rights, UN Doc. A/73/396, 
social protection, ${ }^{77}$ not to mention the impacts of climate change ${ }^{78}$ and international trade and finance ${ }^{79}-$ is clearly immense. ${ }^{80}$

Finally, in connecting the normative framework to the practical task of eliminating poverty on the ground, it is also important to remember the variety of means by which a human rights-based approach to poverty can be implemented, including strategic litigation, advocacy and social mobilisation. ${ }^{81}$ Research has shown that the choice of approach should be context dependent and that a 'strategic and targeted approach (adapted according to the sector, the rights holders and the duty-bearers)' is key. ${ }^{82}$ This necessarily raises the challenge of educating on rights-related aspects of poverty so as to counteract the damaging narratives that shape negative responses, and to empower victims of poverty to mobilise for change. ${ }^{83}$

26 September $2018<$ https://www.ohchr.org/EN/Issues/Poverty/Pages/Privatisation .aspx $>$ accessed 23 July 2020.

77 Magdalena Sepúlveda and Carly Nyst, The Human Rights Approach to Social Protection (Ministry of Foreign Affairs of Finland, 2012). See $<$ https://www.ohchr.org/ Documents/Issues/EPoverty/HumanRightsApproachToSocialProtection.pdf $>$ accessed 23 July 2020. See also the Report of the Special Rapporteur on Extreme Poverty and Human Rights on Digital Technology, Social Protection and Human Rights, UN Doc. A/74/493, 11 October $2019<$ https://www.ohchr.org/EN/Issues/Poverty/ Pages/DigitalTechnology.aspxhttps://www.ohchr.org/EN/Issues/Poverty/Pages/ DigitalTechnology.aspx> accessed 23 July 2020.

78 Report of the Special Rapporteur on Extreme Poverty and Human Rights on Climate Change and Poverty, UN Doc. A/HRC/41/39, 25 June $2019<$ https:// digitallibrary.un.org/record/3810720? ln=en> accessed 23 July 2020.

79 For an example of an accessible overview of all of these issues and their relationship to poverty and human rights, see Kate Donald and Jens Martens, 'The Increasing Concentration of Wealth and Economic Power as an Obstacle to Sustainable Development - And What To Do About It' (Reflection Group on the 2030 Agenda for Sustainable Development, 2018) <https://www.2030spotlight.org/en/ book/1730/chapter/1-increasing-concentration-wealth-and-economic-power-obstacle -sustainable> accessed 23 July 2020.

80 In his final report as Special Rapporteur on Extreme Poverty and Human Rights to the Human Rights Council, Philip Alston explained how the dramatic interplay between these various issues has resulted in a world 'that is not even close to ending poverty' - a failure that is set to intensify in the light of COVID-19 and the inadequate approach of the Sustainable Development Goals and the 2030 Agenda to ending poverty and inequality: The Parlous State of Poverty (n 4).

81 Morten Broberg and Hans-Otto Sano, 'Strengths and Weaknesses in a Human Rights-Based Approach to International Development: An Analysis of a Rights-Based Approach to Development Assistance Based on Practical Experiences' (2018) 22(5) The International Journal of Human Rights 664-80, 675.

82 ibid 676.

83 See Donald and Mottershaw (n 27) 15-33. See also Ruth Lister, 'Power, Not Pity: Poverty and Human Rights' (2013) 7(2) Ethics and Social Welfare 109-23. For 
The purpose of this collection is to drill further into current debates on the role of human rights in addressing poverty, and to amplify with even greater precision the challenges that need to be confronted for human rights to remain relevant and meaningful in the fight against poverty. The contributions straddle a range of disciplinary perspectives, including history, philosophy, politics, law, economics and social justice, and are arranged in two parts. The chapters in Part I critically examine the relationship between human rights and poverty from a theoretical perspective and variously explore the tensions and contradictions inherent in the mix. The chapters in Part II comprise a series of case studies which highlight some of the obstacles and difficulties faced in seeking to implement human rights-based approaches to poverty and development, as well as the efficacy of state-led initiatives on the ground.

Chapter 2 opens with a dialectic between Vittorio Bufacchi and Jesse Tomalty which effectively brings to the fore ongoing contestations within philosophy about the nature of human rights and their possible relationship to poverty. Beginning with an overview of some of the main arguments raised by philosophers regarding that question, Bufacchi argues that the conceptual linkage between poverty and human rights is no more than a superfluous, rhetorical move, in that it adds nothing to moral condemnation of poverty as wrong and an injustice. He argues further that the characterisation of poverty as a human rights violation is counterproductive in that it serves as a distraction from the injustice of poverty, while offering no solution, risking rights inflation and ultimately harming the culture of human rights. Bufacchi reinforces his argument with the observation, contra philosopher Jesse Tomalty, that the linkage argument fares no better when the question of a right to subsistence (and hence the notion of poverty as a violation of human rights) is approached from a legal point of view. The chapter ends with a rejoinder from Tomalty, who refutes Bufacchi's argument on the basis that it is premised too narrowly on an interventionist theory of human rights. The real value, in her view, of Bufacchi's piece is that it reminds us that in contemplating whether poverty is a violation of human rights, much depends on the theory of human rights being applied.

In Chapter 3, Graham Finlay examines some of the most influential international justice theories on extreme poverty and human rights against the

an excellent example of how the framing of issues in human rights language helps to empower victims to mobilise for change, see the case study by Rory Hearne and Padraic Kenna, 'Using the Human Rights Based Approach to Tackle Housing Deprivation in an Irish Urban Housing Estate' (2014) 6(1) Journal of Human Rights Practice 1-25. 
background of the Chinese development model. Beginning with an overview of the Chinese model, he argues that the success of the latter in lifting hundreds of millions of people out of extreme poverty is vitiated by its failure to incorporate key human rights principles necessary for the eradication of poverty, that is, security from poverty and the agency of the poor in the form of transparency, accountability and participation. The chapter goes on to explore the extent to which consequentialist theories expounded by Thomas Pogge, Henry Shue, Amartya Sen and Martha Nussbaum are vulnerable to the sorts of trade-offs involved in the Chinese model, before concluding that the trumping role of rights, elaborated by philosopher James Griffin, has the most potential to avoid the human rights deficiencies of the Chinese model.

Chapters 4 and 5 explore some of the structural impediments that exist in international human rights law which serve to inhibit its capacity to combat poverty. In Chapter 4, Julia McClure argues from a historical perspective that the development of private property as a legal right in pre-modern Europe and its promulgation in both constitutional law and international human rights law have had an undeniably constitutive role in generating poverty and the regimes of inequality that maintain it. Her account is juxtaposed with that of Samuel Moyn, who situates his critique of the international human rights movement's engagement with inequality in a particular socio-economic and political moment. Tracing the history of law and its relation to property from the Middle Ages, McClure demonstrates how property rights have consistently taken precedence over subsistence rights, ultimately concluding that in order to address this imbalance, historical debates about the meaning and function of property as well as differential power relations will need to be revisited.

In Chapter 5, Anna Chadwick highlights a disjuncture at the heart of international human rights law, which is assumed to be politically neutral as to the delivery of rights, yet at the same time appears to support and even require their fulfilment through a capitalist market economy which, she argues, is fundamentally at odds with the realisation of socio-economic rights. In so doing she exposes a gap in human rights scholarship, which tends to avoid the question of whether capitalism is compatible with international human rights law and, in doing so, to forestall important questions concerning what modes of political and economic governance are required to address poverty and realise human rights. In building her argument and in her account of 'capitalism' as a mode of political economy Chadwick draws on a wide body of interdisciplinary literature; she concludes with some reflections on the changes in strategy that the international human rights movement will need to take on board in confronting the fundamental dilemma identified.

In Chapter 6, Su-Ming Khoo explores a series of connected challenges facing the human rights community in the context of extreme poverty, inequality, political power and biological life. These include the challenges posed by 
minimalist definitions of poverty and widening inequality which, she argues, serve to undermine rights universalism and its implicit commitment to social solidarity through fair resource distribution. Khoo highlights a series of threats to the realisation of rights which are posed by emerging, posthuman technologies and are buttressed by law's support of excess wealth accumulation and capital. These include the threats posed to first generation civil and political rights by 'algocracy' (governance by algorithm); to second generation rights by 'pharmocracy' (the global hegemony of the multinational pharmaceutical industry); and to third generation rights by 'chemocracy' (the influence of the chemical industry). In order to counter these challenges, she concludes, the human rights community will need to consider the political, human and ecological costs that these various technologies have inflicted, as well as the relationship between them and excessive wealth accumulation, inequality and processes of regulation.

In Chapter 7, Wouter Vandenhole considers the challenges posed to the realisation of economic, social and cultural rights (ESC) by the demands of sustainable development. Drawing on scientific findings in regard to planetary boundaries as well as insights from the field of ecological economics, he explores the implications for ESC rights of a shift from the economic growth paradigm to one of growth agnosticism, or a-growth. He argues that while a-growth will not necessarily challenge existing interpretations of 'progressive realisation', 'regressive measures' and 'minimum core obligations', it will nonetheless bring issues of distribution and socio-economic inequality to the forefront thus necessitating a new conceptual foundation for the realisation of ESC rights. He concludes with a proposal that this new conceptual foundation can be found in a reinvigorated human rights legal principle of equality that will foster socio-economic distribution and make human rights 'more distributive by design'.

Part I of the book concludes with Chapter 8, by Lonneke Peperkamp and Ronald Tinnevelt, which explores the most radical theoretical strategy by which the global poor might claim their subsistence rights to an adequate standard of living: through the use of military force. The central question examined in this chapter is whether the global poor, suffering from a severe lack of means of subsistence, could wage a just war against the global rich. This chapter thus fills a gap in contemporary political theory which fails to engage substantially with the question of subsistence wars. Given the seriousness of global poverty, together with population growth and increasing shortages in natural resources, the authors argue that this issue deserves broader discussion. Based on an analysis of conventional just war theory and its 'revisionist' school vis-à-vis the justification for subsistence wars, they conclude that the former can accommodate the concept and that there is a consequent need for conventionalists to engage with this debate. 
The case studies in Part II of the book begin in Chapter 9 with an analysis by Aoife Daly and Alan Connolly of the feasibility of incorporating socio-economic rights into domestic law as a means of tackling the impact of austerity in the United Kingdom (UK). They argue that while incorporation would be legally possible without breaching the separation of powers, a more practical obstacle to legal implementation of socio-economic rights is the negative perception of human rights generally in the UK. They suggest that a factor driving such problematic attitudes to human rights, however, might be the failure to implement socio-economic rights. Pointing to research which shows broad support for social rights among the general public in the UK, they argue that much greater emphasis needs to be placed by the human rights community in the UK on social rights issues, not only as a means of tackling poverty, but also to boost the popularity of the human rights framework in the UK generally.

In Chapter 10, María Dalli conducts a human rights impact assessment of the design and operation of social assistance (SA) schemes (aimed at providing 'last-resort' income support benefits to individuals and families with economic difficulties) in Ireland and Spain. Drawing on the recognition given to the right to social assistance in international human rights law, as well as on the findings of the European Committee on Social Rights and the UN CESCR, Dalli points to numerous deficiencies in the schemes operating in each country, including as regards levels of benefits, as well as with respect to age and residence requirements. She concludes, however, that the monitoring activities of international bodies do not cover all issues of concern from a human rights perspective with SA schemes and that regard must be had therefore to the essential role played by civil society organisations and national human rights institutions in evaluating SA schemes, and to their recommendations for improvement. To wit, a strong collaboration is required between human rights supervisory bodies and civil society in this endeavour.

The final chapter of the collection, Chapter 11, is an evidence-based study of the operation of a human rights-based approach (RBA) to development conducted at State level in India involving female community workers ('anganwadi workers') for the Integrated Child Development Services. The women involved (many of whom apply for the post in order to combat their own poverty) are responsible for implementing crucial health and education services for children and other vulnerable categories of people through local centres in their communities. The aim of the study was to examine the 'lived experiences' of these female workers in their duty-bearing roles, and the implications therefore for RBAs to development. The chapter is framed by a theoretical overview of and critical discourses on RBAs to development generally. Based on interviews with anganwadi workers and helpers across three districts in Odisha State, Mishra's study finds widespread feelings of 
worthlessness experienced by the women in fulfilling their roles on account of unresolved practical difficulties (including inadequate budgets, remuneration, facilities and lack of respect within the community), which ultimately drives many to join workers' trade unions. Mishra's study provides evidence of the phenomenon of 'feminisation of obligation and responsibility' previously identified in development programmes, and how experiences of disrespect can ultimately lead poor, vulnerable women to claim their rights. It also provides unique insights for discourses on RBAs to development on the importance of factoring in the voices of poor, grassroots duty-bearers in the design and evaluation of programmes.

The collection closes with an Afterword by Anna Chadwick which reflects on the themes of the book and offers some thoughts on future strategies for the human rights movement going forward. These reflections take into account the context of the coronavirus crisis, which emerged after the chapters for this collection had been authored by contributors to the volume. 